\title{
Comparative Study between Endovenous Laser Ablation and Conventional Surgery of Primary Varicose Veins of Lower Limbs
}

\author{
MOHAMED E. EL-SHENAWY, M.D.*; ATEF A. DESOUKI, M.D.**; AHMED A. KHALIL, M.D.* and \\ KAMAL M. KAMAL, M.Sc.* \\ The Departments of General Surgery* and Vascular Surgery**, Faculty of Medicine, Ain Shams University
}

\begin{abstract}
Background: Varicose veins are the main manifestations of chronic venous disease (CVD), and present as dilated and elongated incompetent superficial veins in the lower limbs. The most common method of treatment for this condition is an open surgery proposed by W. Keller 110 years ago. Endovenous LASER ablation (EVLA) was proved to be effective in the treatment in many randomized controlled trials.
\end{abstract}

Aim of Study: To throw light and compare (EVLA) to conventional surgery in treating primary varicose veins in lower limbs.

Patients and Methods: This prospective study included 40 patients, who were treated for symptomatic varicose veins of the lower limbs divided into two groups. In first one, 20 patients underwent open surgery (the surgery group), while in the other, 20 patients received the EVLA (the EVLA group). The patients were invited to follow-up evaluations at first and second weeks then one and six months after the surgery.

Results: VCSS scores at one month were better in the EVLA group (median VCSS scores 1 (0-2) vs. 4 (3-5), $p<$ $0.0001)$. Patients in the EVLA group experienced less postoperative pain $(p<.00163)$. In addition, patients in the EVLA group managed to return to work and normal activities sooner than those in the surgery group $(p<0.0001)$. No statistically significant differences were found between groups for overall satisfaction, rate of complications except hematoma which was higher in surgery group.

Conclusion: Both treatment techniques yielded similar results in terms of efficacy, complications and overall patient satisfaction. However, early postoperative results in the EVLA group were superior to those of patients in the surgery group.

Key Words: Varicose veins - Endovenous laser ablation (EVLA) - Open surgical treatment - Quality of life - Venous clinical severity score.

\section{Introduction}

VARICOSE veins in the lower limbs are one of the most prevalent diseases presenting in $10-20 \%$ of the adult population [1]. The widespread of the pathology increases with age from $12 \%$ in the age

Correspondence to: Dr. Kamal M. Kamal,

E-Mail: kamal.makram@med.asu.edu.eg group of $18-24$ years to $56 \%$ in individuals aged 55-64 years [2]. While major risk factors are age and family history for both sexes, pregnancy is an additional risk factor for women. Besides, standing for long periods, obesity and female gender are reported as risk factors [3].

Clinical manifestation of this disorder include aching and pain of the lower limbs, muscle cramps, skin irritation, swelling and can result in complications including bleeding, lipodermatosclerosis and ulceration [4]. The clinical signs and symptoms of venous disease may be classified using the CEAP (clinical status, etiology, anatomy and pathophysiology) classification. The degree of severity of pain and other clinical signs or symptoms can be measured using the Venous Clinical Severity Score (VCSS); the change of (VCSS) before and after the intervention can be used to measure the efficacy of intervention [4]

The aim of investigations in patients with a clinical diagnosis of varicose veins is to identify the site(s) of venous incompetence responsible for their development. For the definitive identification of the source of reflux DUS is the investigation of choice and is mandatory when assessing patients who have, or are suspected to have had a previous deep vein thrombosis [5]

The main objectives of the treatment for varicose veins include prevention of complications, alleviation of symptoms, and improvement of the patients' quality of life. The most common method of treatment for this condition is an open surgery proposed by W. Keller 110 years ago [2]. The last decade has seen the advent of endovenous therapies which have been evolving rapidly.

During a surgical procedure, the saphenofemoral junction is disconnected from the venous 
system via ligation in the case of the great saphenous vein disease or the sapheno-popliteal junction is ligated in the case of the small saphenous vein damage. The ligation is usually followed by the great or the small saphenous vein removal (stripping). The surgical intervention usually alleviates the symptoms and yields the desired results, yet some-times the postoperative period is aggravated by the development of complications such as pain, bleeding, infection (inguinal or popliteal), thrombophlebitis, saphenous nerve damage, or impaired lymph drainage. Furthermore, the procedure leaves postoperative scars and there is a risk of hyperpigmentation. Moreover, recurrent varicose veins are known to be a common problem after surgery: The literature demonstrates a recurrence rate of $60 \%$ after 5 years of follow-up observation [6]. The recurrence is mostly caused by neovascularization, anatomic peculiarities (e.g. a double great saphenous vein), surgical technique errors, or an incomplete procedure [7]

Endovenous Thermal Ablation include and endovenous LASER ablation (EVLA) treatment in 2001 [8]. Endovenous ablation involves inserting and passing a catheter or fibre along the lumen of varicose veins under ultrasound guidance. Tumescent, a diluted local anaesthetic (for example diluting $30 \mathrm{ml}$ of $2 \%$ lidocaine and 1:200,000 adrenaline in $500 \mathrm{ml}$ of normal saline) is usually infiltrated into the surrounding tissues of the varicose veins to be treated. Tumescent infiltration also protects the surrounding tissues from injury. Ablation of the varicose veins is then performed with laser. This can be done under general or local anaesthesia. Overall, Technical success rates with EVLA have been found to be excellent with occlusion rates reported to be around $97 \%$ at 4 years and $87 \%$ at 6 years. Therefore, EVLA is considered better than surgery in terms of technical success rate [9].

Aim of the work:

The study is to compare between conventional surgery and endovenous laser ablation in treatment of primary varicose veins of lower limbs.

\section{Patients and Methods}

\section{Study setting:}

Patients recruited from Ain Shams University (El-Demerdash), El-Sahel Teaching Hospitals and other authorized hospitals under the supervision of thesis.

Study period: Six months from November 2020 to May 2021.

\section{The studied population:}

This study is a prospective interventional analytical trial including 40 patients being treated for primary great saphenous varicose veins of lower limbs. Patients were divided into 2 groups (20 patients in each group). First group: 20 patients will have conventional surgery. Second group: 20 patient will receive EVLA.

\section{Inclusion criteria:}

- Age between 18 and 70 years.

- Primary great saphenous reflux on duplex imaging and requiring intervention.

- Duplex scan confirmed suitability for conventional surgery and EVLA.

- Physical condition allowing ambulation after the procedure.

- Patient is able to give informed consent.

- Availability of patients for all follow-up visits.

Exclusion criteria:

- Varicose veins without GSV incompetence on duplex imaging.

- Associated small saphenous or deep venous incompetence on duplex imaging.

- Thrombus in GVS.

- Concomitant peripheral arterial disease (ankle brachial pressure index $<0.9$ )

- Pregnancy.

- Oral anticoagulant.

- Immobilization.

Data collection and analysis:

Patients who were found eligible for the study were asked to sign a written consent to participate in the study. Prior to the intervention, patients' demographic data (sex, age at the time of the treatment, and BMI) were collected, the clinical grade according to the CEAP classification was recorded. The severity of the symptoms was evaluated using the Venous Clinical Severity Score (VCSS). This is an instrument based on the evaluation of nine main symptoms of the disease: Pain, varicose veins, venous oedema, skin pigmentation, inflammation, induration, and ulcers (duration, number, and size of active ulcers) [10]. The total score ranges from 0 (represents no significant venous disease) to 30 (maximum). The postoperative complications and Post procedural pain scores and the intake of analgesics were evaluated during the first seven days after the procedure at the end of the day. Pain scores were taken by the patient with the help of a $10-\mathrm{cm}$ visual analogue scale $(0$ - no pain, 10 - the greatest pain). In addition, the 
time needed to return to normal activity and work was also registered.

\section{Intervention:}

All patients were marked before the surgery or EVLA using guidance by duplex ultrasonography.

An open surgery was performed under spinal anaesthesia. The saphenofemoral junction was ligated and the respective trunk was stripped.

EVLA was performed under perivenous tumescent anaesthesia with $0.05 \%$ lidocaine. The procedure started with a percutaneous insertion of a 19$G$ needle into the affected venous trunk under ultrasound guidance. Subsequently, a guidewire was passed through the. Then the needle was removed, and a 5-Fr catheter was inserted over the guidewire. Finally, the guidewire was removed and an optical fibre was inserted approximately 1$2 \mathrm{~cm}$ distal from the saphenofemoral junction. The laser energy was obtained by applying a 1470-nm diode laser generator probe with a radial-tip fibre (Endotherme1470, LSO Medical, France). A 400micron fibre and the power of $6 \mathrm{~W}$ was used for ablation of small diameter veins $(6-7 \mathrm{~mm})$, while a 600 -micron fibre and the power of $10 \mathrm{~W}$ was used in cases of bigger diameter veins. Our protocol totally delivered $7 \mathbf{J} \times$ diameter of vein $(\mathrm{mm})$ of laser energy per $\mathrm{cm}$ of treated vein. During the infrapopliteal ablation procedure, the amount of energy was modified by the time of exposure according to the diameter of the vein. In both patient groups, the varicosities and incompetent perforators in the thigh and/or the calf were removed by performing mini-phlebectomies via stab incisions over varicose tributaries, which were avulsed using a vein hook or a Kocherised mosquito clamp.

\section{Postoperative care:}

The postoperative management was the same for both groups. After the procedure, a compression bandage was applied on patient's leg. After 48 hours, the patient removed the bandage and continued using an elastic class II compression stocking during the day only for at least one week after the operation. All patients were advised to mobilise immediately after the treatment. In addition, the patients were administered analgesics for pain management postoperatively.

\section{Follow-up:}

All Patients were advised to come for followup visits first and second week then one and six months after the procedure in the outpatient clinics to assess them clinically for improvement of vcss and post-operative complications.

\section{Statistical analysis:}

Recorded data were analyzed using the statistical package for social sciences, version 23.0 (SPSS Inc., Chicago, Illinois, USA). Values were expressed as means \pm standard deviation (SD).

Probability ( $p$-value): * $p$-value $<0.05$ was considered significant, $* * p$-value $<0.001$ was considered as highly significant, $p$-value $>0.05$ was considered insignificant.

\section{Results}

\section{I- Demographic data results: Table (1)}

Sex:

In group A (surgery group) there is 9 male patients $(45 \%)$ and 11 female patients $(55 \%)$ and in group B (laser group) There is 8 male patients $(40.0 \%)$ and 12 female patients $(60.0 \%)$ without statistical significant difference between both groups ( $p$-value 0.7566$)$.

Age:

The mean age of group A (surgery group) was (32.45 \pm 8.24 years), and the mean age of group B (laser group) was ( $31.45 \pm 8.24$ years) without statistical significant difference between both groups ( $p$-value was 0.7032 ).

\section{Body mass index:}

The mean BMI of group A (surgery group) was (26.350 \pm 4.535$)$, and the mean BMI of group B (laser group) was $(26.015 \pm 4.477)$ without statistical significant difference between both groups ( $p$ value was 0.761 ).

\section{II- CEAP classification: Table (2)}

In group A (surgery group) There is 6 patients $(30.0 \%)$ with CEAP classification grade 2,6 patients $(30.0 \%)$ with CEAP classification grade 3 , 8 patients $(40.0 \%)$ with CEAP classification grade 4 and in group B (laser group) there is 5 patients $(25.0 \%)$ with CEAP classification grade 2 , and 7 patients $(35.0 \%)$ with CEAP classification grade 3,8 patients $(40.0 \%)$ with CEAP classification grade 4 without statistical significant difference between both groups ( $p$-value 0.3484 ).

\section{III- Venous clinical severity score: Tables $(3,4,5)$}

Compared with the preoperative scores, at six months after the treatment the VCSS scores statistically significantly improved in both patient groups $(p<0.001)$. 
Preoperative, there was no difference in the VCSS scores between the analyzed groups ( $p$-value 0.1441 ). One month after the treatment, the VCSS score in the surgery group was statistically significantly $(p<0.001)$ higher. However, at six months after doing intervention the VCSS scores converged and the difference between the groups was no longer statistically significant.

\section{IV- Early postoperative pain and analgesia use:}

Table (6)

The median visual analogue score of group A (surgery group) was (4), and the median VAS of group B (laser group) was (2) with statistical significant difference between both groups ( $p$ value was $(0.00163)$.

As a result of this, a higher proportion of patients in the surgery group required supplementary analgesic drugs during the first week after the procedure.

\section{$V$ - Time needed to return to work: Table (6)}

The median duration of time needed to return to work after the treatment was $11.50 \pm 4.47$ days (range 5-20) in the surgery group and 5.40 \pm 2.87 days (range 2-11) in the EVLA group with highly statistically significant difference $(p<0.001)$.

\section{VI- Adverse events: Table (7)}

The analysis of clinical adverse events did not yield any statistically significant results except hematoma which occurred in $25 \%$ of group A $(n=5)$ with no patients in group B. $p$-value 0.01619 .

\section{VII- Overall satisfaction: Table (8)}

At six months after the intervention $90 \%(n=18)$ of the patients in the EVLA group and $80 \%(n=16)$ of the patients in the surgery group claimed that they would choose the same technique if they needed such treatment again or would recommend this technique to others ( $p=0.3888)$.

Table (1): Comparison between both groups regarding sex, age, BMI distribution.

\begin{tabular}{|c|c|c|c|c|c|}
\hline & $\begin{array}{c}\text { Group A } \\
\text { (Surgery) } \\
\text { No.=15 }\end{array}$ & $\begin{array}{c}\text { Group B } \\
\text { (Laser) } \\
\text { No. }=15\end{array}$ & $t$ & $\begin{array}{c}p- \\
\text { value }\end{array}$ & Sig. \\
\hline \multicolumn{6}{|l|}{ Sex: } \\
\hline Male & $9(45 \%)$ & $8(40.0 \%)$ & -0.3121 & 0.7566 & NS \\
\hline Female & $11(55 \%)$ & $12(60.0 \%)$ & & & \\
\hline \multicolumn{6}{|c|}{ Age: } \\
\hline Mean \pm SD & $32.45 \pm 8.24$ & $31.45 \pm 8.24$ & 0.3839 & 0.7032 & NS \\
\hline Range & $20-47$ & $19-49$ & & & \\
\hline \multicolumn{6}{|l|}{ BMI: } \\
\hline Mean \pm SD & $26.350 \pm 4.535$ & $26.015 \pm 4.477$ & 0.2351 & 0.8154 & NS \\
\hline Range & $18.7-33.2$ & $18-33.4$ & & & \\
\hline
\end{tabular}

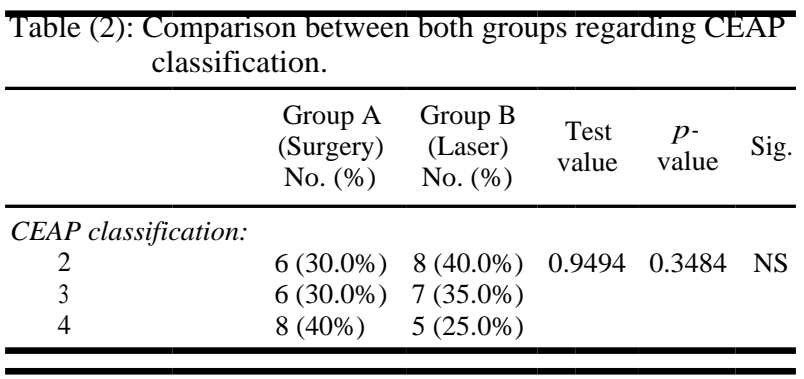

Table (3): Presents the comparison between both group regarding VCSS scores after different periods of treatment and with VCSS pre-operatively.

\begin{tabular}{|c|c|c|c|c|}
\hline VCS S & $\begin{array}{c}\text { Group A } \\
\text { (Surgery) } \\
\text { No. }=20\end{array}$ & $\begin{array}{c}\text { Group B } \\
\text { (Laser) } \\
\text { No. }=20\end{array}$ & $\begin{array}{c}p- \\
\text { value }\end{array}$ & Sig. \\
\hline \multicolumn{5}{|l|}{ Pre-operative: } \\
\hline Median (IQR) & $5(4-6)$ & $5(4-6)$ & 0.1441 & NS \\
\hline Range & $3-7$ & $3-6$ & & \\
\hline \multicolumn{5}{|l|}{$\begin{array}{l}\text { Post-operative } \\
\text { (one month): }\end{array}$} \\
\hline Median (IQR) & $4(3-5)$ & $1(0-2)$ & 0.0001 & HS \\
\hline Range & $3-6$ & $0-2$ & & \\
\hline \multicolumn{5}{|l|}{$\begin{array}{l}\text { Post-operative } \\
\text { (six monthes): }\end{array}$} \\
\hline Median (IQR) & $1(0-2)$ & $1(0-2)$ & 0.1257 & NS \\
\hline Range & $0-2$ & $0-2$ & & \\
\hline
\end{tabular}

Table (4): The VCSS scores after different periods of treatment and with VCSS pre-operatively in group (A).

\begin{tabular}{|c|c|c|c|c|c|}
\hline \multirow{2}{*}{ VCS S } & \multicolumn{3}{|c|}{$\begin{array}{l}\text { Group A } \\
\text { (Surgery) }\end{array}$} & \multicolumn{2}{|c|}{$\begin{array}{l}\text { Friedman } \\
\text { test }\end{array}$} \\
\hline & $\begin{array}{c}\text { Pre } \\
\text { operative }\end{array}$ & $\begin{array}{l}\text { One } \\
\text { month }\end{array}$ & $\begin{array}{c}\text { Six } \\
\text { months }\end{array}$ & $\begin{array}{c}p- \\
\text { value }\end{array}$ & Sig. \\
\hline Median (IQR) & $5(4-6)$ & $4(3-5)$ & $1(0-2)$ & 0.0001 & HS \\
\hline Range & $3-7$ & $3-6$ & $0-2$ & & \\
\hline
\end{tabular}

Table (5): The VCSS scores after different periods of treatment and with VCSS pre-operatively in group (B).

\begin{tabular}{|c|c|c|c|c|c|}
\hline \multirow{2}{*}{ VCSS } & \multicolumn{3}{|c|}{$\begin{array}{c}\text { Group B } \\
\text { (Laser) }\end{array}$} & \multicolumn{2}{|c|}{$\begin{array}{l}\text { Friedman } \\
\text { test }\end{array}$} \\
\hline & $\begin{array}{c}\text { Pre } \\
\text { operative }\end{array}$ & $\begin{array}{c}\text { One } \\
\text { month }\end{array}$ & $\begin{array}{c}\text { Six } \\
\text { months }\end{array}$ & $\begin{array}{c}p- \\
\text { value }\end{array}$ & Sig. \\
\hline Median (IQR) & $5(4-6)$ & $1(0-2)$ & $1(0-2)$ & 0.0001 & HS \\
\hline Range & $3-6$ & $0-2$ & $0-2$ & & \\
\hline
\end{tabular}

Table (6): The comparison between both groups regarding early post-operative pain and time needed to return to work.

\begin{tabular}{llllll}
\hline & $\begin{array}{c}\text { Group A } \\
\text { (Surgery) } \\
\text { No.=20 }\end{array}$ & $\begin{array}{c}\text { Group B } \\
\text { (Laser) } \\
\text { No.=20 }\end{array}$ & $\begin{array}{c}\text { Test } \\
\text { value }\end{array}$ & $\begin{array}{c}p \text { - } \\
\text { value }\end{array}$ & Sig. \\
\hline $\begin{array}{l}\text { Post-operative pain: } \\
\text { Median (IQR) }\end{array}$ & $4(3-6)$ & $2(1-4)$ & 3.392 & 00163 & $\mathrm{~S}$ \\
$\quad$ Range & $2-9$ & $1-7$ & & & \\
$\begin{array}{l}\text { Time needed to } \\
\text { return to work: }\end{array}$ & & & & & \\
$\quad \begin{array}{l}\text { Mean } \pm \text { SD } \\
\text { Range }\end{array}$ & $11.50 \pm 4.47$ & $5.40 \pm 2.87$ & 5.1371 & 0.000 & $\mathrm{HS}$ \\
\hline
\end{tabular}


Table (7): Comparison between both groups regarding adverse events.

\begin{tabular}{llllll}
\hline $\begin{array}{l}\text { Adverse } \\
\text { events }\end{array}$ & $\begin{array}{c}\text { Group A } \\
\text { (Surgery) } \\
\text { No.=20 }\end{array}$ & $\begin{array}{c}\text { Group B } \\
\text { (Laser) } \\
\text { No.=20 }\end{array}$ & $\begin{array}{c}\text { Test } \\
\text { value }\end{array}$ & $\begin{array}{c}p- \\
\text { value }\end{array}$ & Sig. \\
\hline Infection & $4(20 \%)$ & $1(5 \%)$ & 1.43535 & 0.159367 & NS \\
Hematoma & $5(25 \%)$ & $0(0 \%)$ & 2.51661 & 0.01619 & S \\
Parathesia & $2(10 \%)$ & $1(5 \%)$ & 0.6518 & 0.51707 & NS \\
Discoloration & $0(0 \%)$ & $2(10 \%)$ & -1.4529 & 0.154442 & NS \\
\hline
\end{tabular}

Table (8): The comparison between both groups regarding overall satisfaction.

\begin{tabular}{|c|c|c|c|c|c|}
\hline $\begin{array}{l}\text { Overall } \\
\text { Satisfaction }\end{array}$ & $\begin{array}{c}\text { Group A } \\
\text { (Surgery) } \\
\text { No. }(\%)\end{array}$ & $\begin{array}{c}\text { Group B } \\
\text { (Laser) } \\
\text { No. }(\%)\end{array}$ & $\begin{array}{c}\text { Test } \\
\text { value* }^{*}\end{array}$ & $\begin{array}{c}p- \\
\text { value }\end{array}$ & Sig. \\
\hline Agree & $16(80 \%)$ & $18(90 \%)$ & -0.871 & 0.3888 & NS \\
\hline Disagree & $4(20 \%)$ & $2(10 \%)$ & & & \\
\hline
\end{tabular}

\section{Discussion}

The study was conducted on 40 patients divided into two groups each one included 20 patients. Group A (surgery group) was managed by standard open surgery for treatment of varicose veins of the lower limb and Group B (laser group) subjected to endovascular laser therapy for treatment of varicose veins of the lower limb.

Both groups were well matched regarding age $(p=0.7032)$ and sex $(p=0.7566)$, CEAP classification $(p=0.3484)$ and also regarding BMI $(p=$ $0.8154)$.

Regarding preoperative venous clinical severity score, the median (IQR) for group A (surgery group) was (5), and for group B (laser group) was (5) without statistical significant differences between both groups $(p$-value $=0.1441)$.

Many studies have shown there were some differences in between the two methods.

Regarding four weeks post-operative VCSS assessment, the VCSS score in the group A (surgery) was statistically significantly higher ( $p<$ 0.001 ). However, at six months after the intervention, The VCSS scores converged and the difference between the groups was no longer statistically significant.

Our study was in agreement with Mantas (2016). This was prospective non-randomized study included 299 patients, who were treated for symptomatic varicose veins of the lower limbs in two centers. In one, 159 patients underwent open surgery (the surgery group), while in the other, 140 patients received the EVLA (the EVLA group).
The patients were invited to follow-up evaluations at six weeks, one year, and two years after the surgery. They found that VCSS scores at six weeks were better in the EVLA group (median VCSS scores $1(0-2)$ vs.4 (3-6), $p<0.001)$ in the surgery group. However, at one and two years after the intervention the VCSS scores converged and the difference between the groups was no longer statistically significant [2]

Regarding postoperative pain and analgesia use in our study. The median visual analogue score of group A (surgery group) was (4), and the median VAS of group B (laser group) was (2) with statistical significant difference between both groups ( $p$-value was .00163).

As a result of this, a higher proportion of patients in the surgery group required supplementary analgesic drugs during the first week after the procedure.

And regarding time needed to return to work The median duration of time needed to return to work after the treatment was $11.50 \pm 4.47$ days (range 5-20) in the surgery group and 5.40 \pm 2.87 days (range 2-11) in the EVLA group with highly statistically significant difference $(p<0.001)$.

Our study was partially agreement with Rasmussen (2007) regarding post-operative pain, in this study Patients with varicose veins due to GSV insufficiency were randomized to either EVL (980nm) or HL/S, Patients were examined preoperatively and at 12 days, 1,3 , and 6 months postoperatively. Sick leave, time to normal physical activity, pain score, use of analgesics, Venous Clinical Severity Score (VCSS), and complication rates were investigated, the total cost of the procedures, including lost wages and equipment, was calculated. They found that Postoperative pain and bruising was higher in the HL/S group, $(p<.01)$ but no difference in the use of analgesics was recorded [12]

Also our study disagrees with this previous study in time needed to return to work as they found that the respective mean times to work (7.6 vs. 7.0 calendar days) did not differ significantly between the HL/S and EVL groups [12].

Our study was in agreement with Darwood (2008) this study include patients with symptomatic varicose veins who were randomized to EVLA 1 (stepwise laser withdrawal), EVLA 2 (continuous laser withdrawal) or surgery (sapheno femoral ligation, GSV stripping, multiple phlebotomies). They found that 22 of 25 and 12 of 16 patients 
returned to work within 1 week of EVLA 1 and EVLA 2 respectively, compared with 9 of 23 surgical patients (median (I.Q.R.) times 4 (2.5-7), 4 (1-12) and $17(7.25-33.25)$ days respectively ( $p=$ $0.005)[13]$.

Also our study disagree with this previous study regarding post-operative pain, they found that Daily pain scores during the first week were generally low, with no difference between the groups at any time point. The median (I.Q.R.) duration of analgesia use was similar for all three groups: 5 (2-7) days after EVLA 1,6 (3-7) days following EVLA 2 and $4(1-7)$ days after surgery $(p=0.497)$.

Regarding overall satisfaction in our study at six months after the intervention $90 \%(n=18)$ of the patients in the EVLA group and $80 \%(n=16)$ of the patients in the surgery group claimed that they would choose the same technique if they needed such treatment again or would recommend this technique to others $(p=0.3888)$.

Our study was in agreement with Theivacumar (2009) they found those At 2 years, patients' satisfaction rates were $90 \%$ and $88 \%$ in the surgery and EVLA groups respectively ( $p 00.37)$. Without statistical significance difference [14]

Also our study was in agreement with Darwood (2008) they found that Satisfaction with treatment outcomes at 3 months, measure done a 100-mm linear visual analogue scale, was high in all three groups with no difference between them (median (I.Q.R.) score 95 (89-98), 91 (84-97) and 91 (8195) after EVLA 1, EVLA 2 and surgery respectively $p=0 \cdot 267$, without statistical significance difference [13] .

\section{Conclusion:}

EVLA is associated with less postoperative pain, less usage of analgesia, less hematoma, faster recovery and work resumption compared with conventional surgery in treatment of primary GSV varicose veins. But overall satisfaction was the same.

\section{Financial support and sponsorship:}

Nil.

\section{Conflict of interest:}

There are no conflicts of interest.

\section{References}

1- STAFFA R.: Chronic venous insufficiency-epidemiology. Bra-tisl Lek Listy, 103: 166-168, 2002.
2- KIEVIS AS M., VELICKA L. and KETURAKIS V.: A comparison of endovenous laser ablation and conventional surgery in patients with varicose veins of the lower limbs, Acta. Angiologica, Vol. 21, No. 4 pp. 107-115, 2016.

3- CARPENTIER P.H., MARICQ H.R., BIRO C., et al.: Prevalence, risk factors, and clinical patterns of chronic venous disorders of lower limbs: A population-based study in France J. Vasc. Surg., 40: 650-659, 2004.

4- CHWALA M., SZCZEKLIK W., SZCZEKLIK M., et al.: Comparison of endovenous laser treatment and high ligationin treatment of limb varicosity: A meta-analysis: Official organ Wroclaw Medical University, 24 (1): 5-1, 2015.

5- JOSEF RAFETTO and ROBERT EBERHARDT: Chronic venous disorder, Rutherford vascular surgery book, ch. 55: 850-857, 2014.

6- GANG CAO, HAN-CHENG GU, et al.: Comparison of endovenous laser treatment and high ligation in treatment of limb varicosity: A meta-analysis Int Wound J., 1-7, 2019.

7- VAN RIJ A.M., JIANG P., SOLOMON C., CHRISTIE R.A. and HILL G.B.: Recurrence after varicose vein surgery: A prospective long-term clinical study with duplex ultrasound scanning and air plethys-mography. J. Vasc. Surg., 38: 935-943, 2003.

8- NESBITT C., EIFELL R.K., COYNE P., BADRI H., BHATTACHARYA V. and STANSBY G.: Endovenous ablation (radiofrequency and laser) and foam sclerotherapy versus conventional surgery for great saphenous vein varices. Cochrane database of systematic reviews, (10): CD005624, 2011.

9- FAN Z.: Clinical comparison of endovenous laser and traditional surgery for varicose veins of lower extremities. Med. J. Chin People's Health, 29: 45-47, 2017.

10- VASQUEZ M.A., RABE E., McLAFFERTY R.B., et al.: Revision of the venous clinical severity score: Venous outcomes consensus statement: special communication of the American Venous Forum Ad Hoc Outcomes Working Group. J. Vasc. Surg., 52: 1387-1396, 2010.

11-RASMUSSEN L.H., BJOERN L., LAWAETZ M., BLEMINGS A., LAWAETZ B. and EKLOF B.: Randomized trial comparing endovenous laser ablation of the great saphenous vein with high ligation and stripping in patients with varicose veins: Short-term results. J. Vasc. Surg., 46 (2): 308-315. doi:10.1016/j.jvs.2007.03.053, 2007.

12- DARWOOD R.J., THEIVACUMAR N., DELLAGRAMMATICAS D., MAVOR A.I.D. and GOUGH M.J.: Randomized clinical trial comparing endovenous laser ablation with surgery for the treatment of primary great saphenous varicose veins. Br. J. Surg., 95 (3): 294-301. doi:10.1002/ bjs.6101, 2008.

13- THEIVACUMAR N.S., DARWOOD R. and GOUGH M.J.: Neovascularisation and Recurrence 2 Years After Varicose Vein Treatment for Sapheno-Femoral and Great Saphenous Vein Reflux: A Comparison of Surgery and Endovenous Laser Ablation. Eur. J. Vasc. Endovasc. Surg., 38 (2): 203-207. doi:10.1016/j.ejvs.2009.03.031, 2009. 


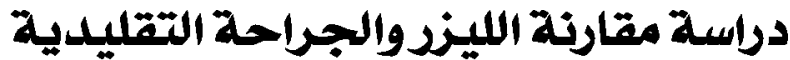

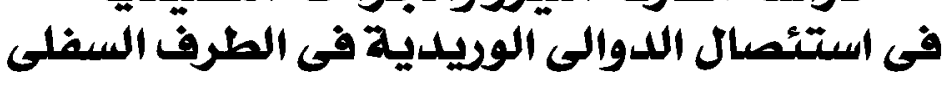

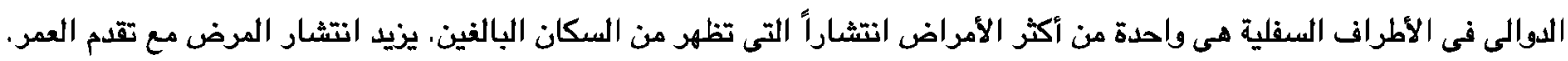

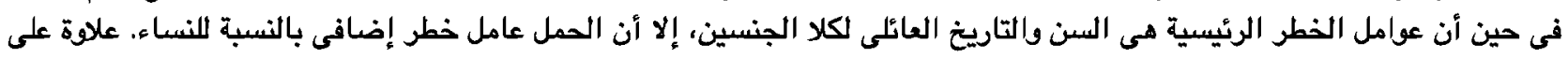
ذالله يتم الإبلاغ عن السمنة ونوع الجنس عند الوقوف لفت الفترات طويلة كعوامل خطر.

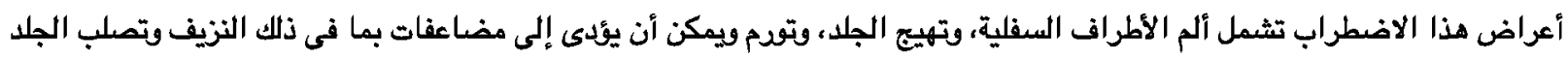

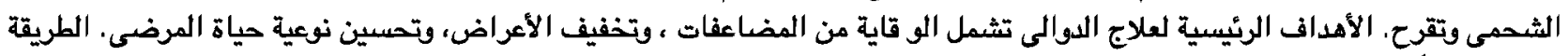

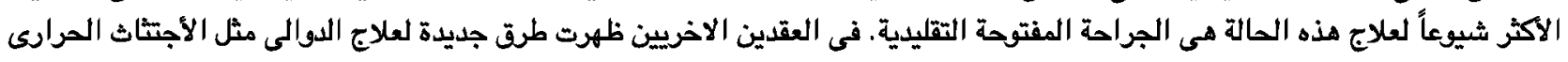
باستخدام الليزر.

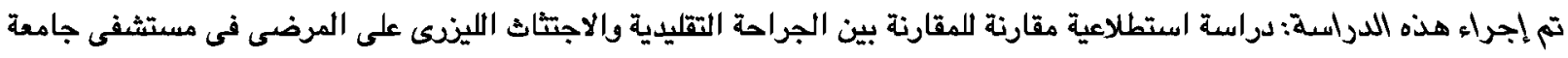

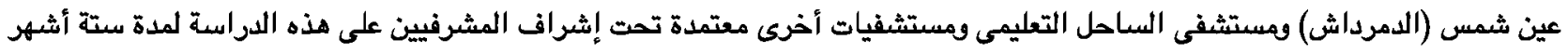

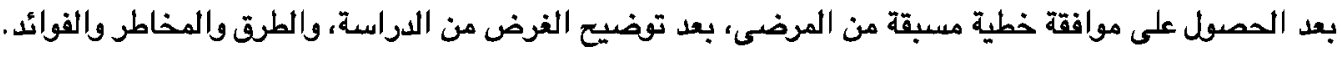
تم إجراء الدراسة على •ع مريضاً، فى مجموعتين (·r مريض فى كل مجموعة) ممن انطبق عليهم معايير الأنضمام اللدراسة. المجموعة الألى تم علاجها باستخدام الجراحة التقليدية، بينما المجموعة الثانية تم ساتخدام الأجتّاث الحرارى بالليزر.

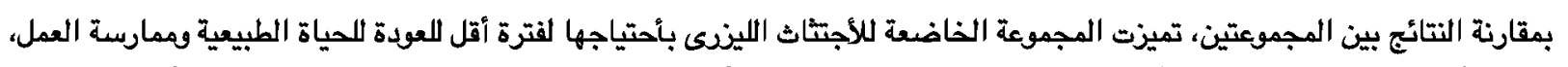

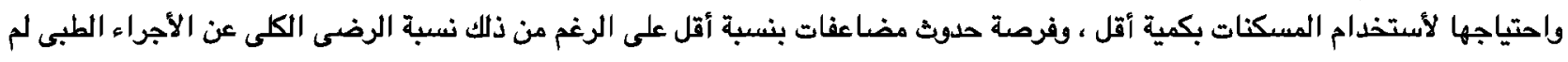
تختلف بين المجموعتين. 